\title{
Investment Decisions And The Parallel Funding Routes: Informal savings as a new tool of funding decision in the Cameroonian SMEs. Emmanuel BEYINA
}

Doctor in Management Sciences of the university of Strasbourg France (Louis Pasteur 2007), HOD University of Bamenda, Cameroon.

\begin{abstract}
The criteria of the choice of investment elaborated by the oricians are based on rationality of deciders who after some work often consider two types of aids to investment decision: delay of getting back invested capital and net actualized value. Whereas other forms of aid to funding decision exist. We are proposing in the framework of this article, a new model of aid to funding decision corresponding to the new informal funding. We think that risk capital in the framework of informal funding (Ndjangi) can bring forth longterm funding as strategy, and solutions to questions of rationality of the heads of Small and Medium size Enterprise (SMEs) that prefers the delay of getting back invested capital, solutions to problems of decision of choice, and at last solutions to the quality of profitability of investments.
\end{abstract}

\section{Resume}

Les critères de choix d'investissement élaborés par les théoriciens sont fondés sur la rationalité des décideurs qui d'après certains travaux considèrent le plus souvent deux types de critères d'aide à la décision d'investir : le délai de récupération du capital investi et la valeur actualisée nette. Pourtant d'autres formules d'aide à la décision existent. Nous proposons dans le cadre de cet article, un nouveau modèle d'aide à la décision de financement correspondant à la finance informelle nouvelle. Nous pensons que le capital risque dans le cadre de la finance informelle (tontinal) peut apporter en tant que stratégie de financement à long terme, des solutions, aux questions de rationalité des dirigeants des PME qui préfèrent le délai de récupération du capital investi, des solutions aux problèmes de décision de choix, et enfin des solutions sur la qualité de la rentabilité des investissements.

Key-Words: investment, funding, informal savings and funding, decision tool.

Mots-clés: investissement, financement, tontines, outil de décision

\section{Introduction}

Investment is the most important long term decision taken by the enterprise. The enterprise does not invest only to review its production equipment but also to insure development of its activity by increasing production capacity or by manufacturing new products (Lepage 2014). Investment decision (Lambert, 1988, 2001) is a strategic decision because it takes in consideration the future of the enterprise. A poor orientation can penalize the life of the enterprise (Mounia, 2016). There are two essential reasons: Investment is an irreversible choice (Bancel F, Richard A. 1995) : it is difficult to give out specific wealth in case of above capacity production; investment requires substantial funds if monetary flows are inferior to anticipated flows, treasury problems would appear since fixed charges must be borne. This is why aiding tools to decision based on the application of quantitative techniques are proposed so as to allow for a better evaluation of investment decision. Invest in the enterprise is putting in place financial means through production activities, sales, and to generate financial resources on several previous periods (Babusiaux, 1990). The idea is that liquidity placement in a project will procure liquidity return to the investor in the first place. Secondary, future profits will be more important than invested capital in the project. Investment also 
engages the enterprise to means and long-term. The enterprises that contracted important availabilities in a risky project would find itself in serious financial difficulties: invested capital would not be remunerated at the expected level; and moreover, insufficient income can make the enterprise to arrive at a stage of suspension of payment (fall due of loans...). Investment problem calls back to selecting projects while comparing investment cost and what it can bring back (Bancel F. Richard. A. 1995), this simply means expected future profits $\mathrm{G} 1, \mathrm{G} 2 \ldots \mathrm{Gn}$. It is a way of presenting investment reality in reducing the problem while considering financial flows, profits, time and rate of profitability but however, much interest should go to the rationality of the decider in the choice of the investment. Every investment model is generally considered as an assisting tool to investment decision (Lambert, 1988): This is why the obtained results must be relativized. In financial matters, the theory established that there is separation of investment decisions and that of funding decisions.

\section{Framework Analysis}

The criteria of making a choice in investment elaborated by rhetoricians are based on the rationality of deciders who more often consider two types of assistance to decision: recuperation delay and actualized net value (Babusiaux 1990). Abundant literature shows that the criteria mostly used is the recuperation delay, actualized net value has been reversed strategically to particular investments. Recuperation delay allows for the choice of a project in function of the time necessary for procured results to equal the putting in place of initial funds. If annual cash flows is not constant, recuperation delay calculation is done on the basis average cash flow or linear interpolation on cumulated cash flows. The decider would opt for a shorter recuperation delay when making a choice from several projects if this acceptable.

The decider will reject any project which the cash flows do not allow for the recuperation of the invested amount, within a given period (Betbeze, 2014). The major problem resulting from this reasoning is that he neglects a large part of information on his project. In effect, the appreciation base is limited to cash flows situated in the recuperation delay. When comparing two projects having different life duration or cash flow profiles, there will be inconvenients. In this case, the recuperation delay can lead in effect to choose the investment of which global profitability is the weakest. From the economic point of view, this decision is less optimal; it is aimed at maintaining a certain level of liquidity in the enterprise. With the criteria of recuperation delay, the principal objective of the decider does not correspond with profit maximization, but the decision is guided by risk minimization of illiquidity that drives to the investment activity. Interest and capital theories have allowed for the construction of criteria where time factor enters in the calculation of profitability by bias: from the choice of actualization rate applied to cash flows reflects the phenomenon of future depreciation; considering a series of cash flow taken from the most characterized criterion to this regard. This criterion consists in bringing actual value, follow up of spread out result within time limit and compare with initial investment expenses. The principle consists in accepting a project when its net actual value is positive or when a comparison between several projects, to choose with one maximizes the criteria. Using this criterion, the agent is pursuing an objective of maximization of profit. The risk aspect of illiquidity is totally absent from the criteria and this leads to a frequent favour of heavy investments of initial input of capital but bringing a mass of more important cash flows. Facing an extreme criteria prudence that represents the recuperation delay, the actualized net value allows for giving an account of global profitability of investment of its life span. Each type of criteria responds perfectly to the rationality of the decider who is a reference. In practice, if the variations of economic environment of the enterprise necessitates an accrued prudence, the entrepreneur passes from the actualized net value criteria to the recuperation delay criteria and vice versa (Thompson, 1985). The existence of intermediary criteria reflect lack of theory that has to be filled by methods of choice sensible to benefit maximization and at the same time the minimization of risk illiquidity: local savings (parallel funding circuits) that would constitute an interesting field of reflexion that would fill this gap. 


\subsection{The Literature Review}

In order to precise the investment decision status (delay of getting back invested capital and net actualized value) within the neo- classical financial theory, it is necessary to present the foundation for this concept as well as the principal elements that constitute it notably, its configuration or non-integrated risk and the different forms of investment rationalities. The neo-classical financial theory (The foundation of the neoclassical financial theory) does not pursue an explanation of investment decisions of organizations objective; it prescribes normative rules aiming at choosing optimal investments (Romelear, 2001), with an objective of maximizing the riches of shareholders considered as exclusive owners of the firm: they are the only people who have the right to take investment decisions (and non-investment) as well as ownership of flows derived from investments (after remuneration of other production factors). In conformity to this objective, the theory proposes the actual net value criteria (ANV) that constitutes a measure of riches created for shareholders. This criteria aims at determining the level of optimal investment if it is possible to represent investment opportunities in the form of continuous curve linking flows derived from investments and invested amounts or decide the acceptability of an investment or an exogenal rationing situation of capital in the choice of different projects. The new investment is optimal; created value is maximized for Shareholders when the ANV supplement brought by the investment marginal franc is useless .Secondly, a project is acceptable and must be carried out if it contributes positively in increasing the riches of shareholders. In the case of capital rationing, the choice of project envelop is done in a manner of maximizing the sum of ANV of these projects, ANV being additive ${ }^{1}$. This normative approach learns on a representation that supposes a certain number of hypotheses related to the actors, markets and the mode of value creation via the investments ${ }^{2}$. The representation finds its origin principally and successively in the representation of investment decision retained in the model of Fisher in this extension permitted by risk evaluation models. In this research of optimal criteria of investment choice, Fisher (1930) proposes a model that ignores risk (The neo-classical theory of Investment in absence of risk) and that has served as the foundation of budgetary theory of investments in the enterprise ${ }^{3}$. The hypothesis of the absence of risk renders all the distinction between different categories of resources contributors (shareholders, creditor...) useless. Funding cost, "capital cost" is equal to a unique interest rate that prevails on the financial market with a competiting reputation. Possibility investment curb of the enterprise is totally independent from actors and translates the state of technology: It is well known. The optimal investment level is determined when there is equality between the marginal profitability rate of investment and the cost of capital. This level that results uniquely from objective elements of confrontation (form of the investment possibility curve and the market interest rate), is itself objective. Partly, there could be difference between shareholders in the choice of optimum (rule of unanimity) and in the other parts, the choice decision (partly controllable) can be delegated to the manager. This agent would make contributors of capital to act automatically without latitude. The ANV criterion is a direct consequence of framework and conforms constructively to the objective of growing riches of shareholders. The ANV of an investment represents the supplement of riches

\footnotetext{
${ }^{1}$ Despite the fact that ANV is an additive does not mean there is contradiction with strategic approaches notably those that are based on competences. This property does not imply that there is independence of projects and that the synergy effects are ignored. These results are linked to the evaluation mode and ANV as well which is differential and incremental. The investment amount and exploitation flows are always evaluated. Differently as compared to the existing synergies as well as external negative effects (for example, product "cannibalization" taken into account.

${ }^{2}$ This representation lies implicitly on a model where two or three classes of actors interverne in the first place (Shareholders, managers and financial debtors) flows from investment are supposed to be risked or not. These actors are provided with illimited substantial rationality. Managers manage shareholder interest and contracts only. Secondly, financial markets where titles are exchanged (shares or debts) are perfectly competitive and informationally efficient. There is no transaction cost. In the hypothesis of capital rationalization, an influence is supposed. Thirdly investment flows depend on technological choice in the strict sense. The manager should be able to know the level of investment, of exploitation flow or exploitation flow of multi-periodic framework associated to him. These flows are given in an exogenal manner, they are independent from all organizational consideration as well as funding choice. Total inseparity is observed between choice of investment and funding.

${ }^{3}$ In reality, the presentation of Fisherian model is implicitely retained in the finance manuals as basics and which is relatively caricatural compared to the original work of Fisher.
} 
that shareholders could consume, the final objective being, maximizing associated utility to consumption. This ANV is obtained by actualizing exploitation liquidity flow to the financial market interest rate, deduction made from the amount of capital invested. To the optimum, or the marginal franc of investment, creation of measured value by the ANV is useless ${ }^{4}$. According to this representation, creation of riches is totally independent from particular preferences of shareholders in inter temporal consumption matter ${ }^{5}$. The notion of retained risk in neo-classical financial theory is particular (The neo-classical theory of investment in the presence of risk). In relation to investment, risk is the result of variability ex-ante of flows in function of the state of the world. Probalities associated to different states are supposed to be known at least in a subjective manner, and the actors are able to construct a distribution of flows probabilities. Contrarily to the uncertain notion as defined by knight, we can quantify in a probabilistic manner, the risk retained notion stays "weak", it is evaluable by actors. Planning of the neo-classical theory in order to allow for the integration of this notion does not modify the representation of investment. The only preoccupation is the evaluation of flows emanating from investment and retained tittles of capital contributors as appreciation rights of flows. Two principal models that allowed for the integration of risk in this evaluation are the Arrow and Debreu $(1956,1959)$ and the model to equilibrate financial assets due notably to Sharpe (1965) and Linter (1985). These two models are based on an hypothesis of substantial rationality of actors that allow for risk representation of quantification. The actors of the Arrow and Debreu models foresee all states of the world and associate them a probability. In revenge to the model of equilibrate ${ }^{6}$ they are able to establish probability distribution directly on different flows. Risk is apprehendable, quantifiable ex-ante; uncertainty in the sense of Knight does not exist in this type of model. In relation to the representation of investment decision, in the Fisherman's model, multiple differences exist ${ }^{7}$. However, precisions outside all imperfection (notably if there is imposition of results), funding of investments is different. According to the famous theorem of Modigliani and Miller (1958), we cannot increase investment value (generally from the assets portfolio representing the firm) choosing a particular funding structure. Risk does not modify the representation of investment decision in the neo-classical theory; all depend on the rationality of the decider.

\subsection{The different forms of investment rationality}

\footnotetext{
${ }^{4}$ Considering the level of created riches, the financial market allows for the maximization of inter temporal utility of consumption by simple transfer in operation means of loans sub tendered by financial titles. Evaluation of riches created necessitates the existence of a financial market as referential. Value is created, because the investments carried out produces more than simple placement on the financial market (or the cost of their funding): Managers are obliged to invest on physical assets as much as marginal profitability remains superior to capital cost. In other words, as much as investment is profitable, it is certain that representation is adopted. The form of profitability is unquestionable.

${ }^{5}$ Independence as compared to particular preferences of shareholders does not means that the actualization rate is not linked to inter temporal preferences. Accountability is rendered in the form of aggregation of the whole market.

${ }^{6}$ MEDAF

${ }^{7}$ Firstly, flows from investments are risky; their amount varies in function of the state of the world. They are supposedly fixed outside the model, they are given even if the necessary information is more complex. We suppose in simple formulations of these models that risk representations are identic to all individuals. Therefore in Medaf version of nase, different shareholders must be able to anticipate profitability expectations in a homogenial manner, variances and covariance for the whole different tittles. Secondly, risk introduction implicates if the existence hypothesis of an asset without risk (assimilated to the title of debts) is retained, two categories of actors are considered and supposed homogenous. The first category is debtors who are not willing to take any risk; they are satisfied to be paid on rate without risk and they do not participate to the sharing of profits. To equilibrate profitability rate integrates risk bonus with consideration given to rational anticipation hypothesis that goes with these models in average and ex past shareholders are perfectly compensated for incurred risk and (it would have been different if we had to consider uncertaintily). By definition, this would not have been envisaged even if was a probability manner, he would not have been attributed a price and would not have been integrated under a quantifiable incentive in the required rate. Within the traditional theory, shareholders are residual debts only in a restrictive and relative sense. The residue is the evaluation of capital cost that serve in actualizing exploitation flow that becomes more complex. The existence of two categories of capital contributors (financial) debtors and shareholders) implicates that the cost of resources funding investments are obtained by ponderation between the cost of financial debts (supposed without risk) and that of personal capital that integrates risk bonus. Medaf, allows for a quantification objective of this bonus and it is possible to evaluate exploitation risk bonuses separatively and financial risk demanded respectively to support exploitation risk (variability of exploitation of flow) and financial risk (supplementary variability due to the gear stick of the debt).
} 
The framework presentation of different forms of rationality are common in the sense that the decider always want to compare envisaged consequences of his investment actions to criteria, reasons for actions and to choose. However, contrary to binary essential presentations of this concept, opposing in one side the profitability standard to irrational intrigues on the other side; we are going to make an attempt in this article to show the complexity of these forms and the continuity that allows for the passing from one form to another. The conducting cable that creates a progressive distortion more or less strong with the standard rational model is constituted by the degree of ambiguity conveyed by decision problem. We find this degree of Knowledge as well as choice alternatives, their consequences rather than deciders preferences. We shall try to explain how deciders face investment decision problems and how the consequences appear to be ambiguous, how constraints, values and effects would take a negligible place in the decision. These elements of appreciation of manager's actions do not put an end to the links with legitimate research of profit of maximization, but distorts the evaluation of investments projects. This distortion will be stronger than ambiguity that characterizes the investor's decisional base. Among the investment decision rationalities, we find first of all substantial rationalities (or piloted by intention or by objective) (maximization of ANV strategic objective, etc.). But conditions of limited rationality impose consideration of weak version (procedural rationality piloted by rules, constraints, values or the affected and contextual rationalities). Despite well-known differences, these forms of rationality are common because they are all based on intentional reasons of optimists. Two other forms will be studied next that corresponds to natural reasoning modes in split with the previous where the decision rule is not stopped and would evaluate as decision is unfold. From the start, unknown preferences would be revealed bit by bit to deciders in a dynamic discovery process or the decision rules varies from choice process to another in function of natural selection (decision by resolution, skim or gliding) in the model of "waste paper basket". This degree of parameter opening of decision characterizes some forms of exploratory rationality calling for incremental hourly discoveries. At the end, let us precise that the proposal made here is not final but constitutes a step towards a better comprehension of multiple modalities in which an investment decider can be rational while being conscious of his own limits, and knowing that the world is a changing one, complex, resided by forces and other actors who influence their investment and must be considered in the rationality that is applied there. In the framework of rationality exploitation (Lambert 1998, 2001), the division we make between rationalities "optimists" and "exploratory rationalities" is undoubtedly a mode of classification. It reflects a difference between versions that the investment decider may have of a world in which his action is registered. In optimist rationalities, the decider considers that he can optimize during the moment of choice while considering all the aspects of the world, his personal limits and values that are his. In the exploratory rationalities, the decider considers that he cannot optimize because the world is changing and it is filled with unknown actors, autonomous and/or foreseeable. The decider knows that his choice may become questionable in function of the space of choice, possibilities of real actions and their efficiency. In these exploratory rationalities, the investment decider focalizes his reflexion more on aspects of social apprenticeship than in other optimist rationalities. We can therefore: try to understand why decision actors adopt rationalities that we $\mathrm{know}^{8}$, orientate management tools, the training of managers and manuals towards better rationalities; and try to determine which modalities and what cost that are possible to bring deciders and enterprises to evaluate on better performance and on rationalities that guide or determine their behavior". These rationalities "optimists" and "exploratory" specify the statute of the investment decision:

\footnotetext{
${ }^{8}$ This part of the research can reveal the existence of problems in the normative rationalities. It is in this sense that Simon has shown that perfect rationality models are not appreciable though they are desirable. They are not applicable in certain decisions (notably investment decisions).

${ }^{9}$ ) Management is therefore a practical science: its objective is not only to describe what exist but also to say what seems optimal. Its project is also to give enterprises the means of action that is useful. This leads the enterprise to include cost and the effects of management tools, actions of advice and of training. This can make the enterprise to consider that in a given context the best actions are not those that are rationally ideal but rather those that are concretely possible for an enterprise to be managed. Interesting knowledge is true knowledge as shareholder knowledge in the sense of Argyris and martinet
} 
delay of getting back invested capital and net actualized value. In the final analysis, we are trying through the developed problematic and in the framework of this article identify firstly rational constructions of Cameroonian SME in other words, justify what makes SMEs to adopt a decision tools compared to another and in the other hand the influence that these rationalities may have on the choice of investments ${ }^{10}$ and notably as compared to recuperation delay of invested capital and the actual net value, and this bring us to question on the types of funding.

\section{Methodology Of Emperical Framework Of Our Study}

SME being the sample unit of our empirical study, we are going to define the concept of SME in the first place, the evidence and secondly the Cameroon context and lastly we shall consecrate on the empirical framework of our study. Generally, the SME is apprehended as quantitative, by the number of employee, its business turnover, the level of personal capital and even the level of its investment, quantitatively (Silem, 1994) as autonomous enterprises where the leader assumes financial responsibilities, technique and social without these elements being disassociated. The absence of a unique and harmonious definition does not easily render all the identification exercise of SME in Cameroon. Nevertheless, on the basis of retained criteria of the usual definitions ${ }^{11}$ of the SME and the possibility to attain easily relative information to these criteria, SME has been considered in our study as satisfying units under the following conditions: it should be managed by national, it should be owned by national, the number of employees should be at least 150 , it must have at least 1000 million FCFA or 1524490 euro $^{12}$ as business turnover. Although it does not have available a precise simple framework responding to the profile of SME retained by our study, we have obtained recalls and annuals of certain professional syndicates such as Gicam (Interpatronal Group of Cameroon) Syndustricam ( Industrial syndicate of Cameroon) Pro-PME (Canadian Organism of SME In Cameroon) pertinent information for the constitution of samples.

\subsection{The empirical Framework of our study}

To reply to the question asked, we carried out an investigation in the SMEs of the City of Douala-Cameroon. We selected commercial, industrial, and services SMEs situated in Douala (Cameroon) as our field of study where we submitted standard questionnaires. The table below retraces the distribution of $60 \mathrm{SME}$ of our study according to sectors of activity.

\section{Table 1: Distribution of 60 Cameroonian SMEs according to sector of activity.}

\begin{tabular}{|l|c|c|}
\hline \multicolumn{1}{|c|}{ Sectors } & $\begin{array}{c}\text { Numbers of } \\
\text { establishments }\end{array}$ & Percentage of establishment \\
\hline General Trade & 12 & 20 \\
\hline Agro - food Industry & 16 & 23,6 \\
\hline Commercial services & 7 & 11,6 \\
\hline Chemical transformation & 2 & 3,4 \\
\hline Paper and carton Industry & 7 & 11,6 \\
\hline Textile and confection & 2 & 3,4 \\
\hline Wood Industry and transformation & 3 & 5 \\
\hline
\end{tabular}

\footnotetext{
${ }^{10}$ The pursue logic is not to affirm validity of a new form of rationality. Our Approach is of two stages, to show that the breakeven of validity models of representation of investment decision is contextual, putting in front complementarity rather than opposition of rationality models. The second would allow for a better comprehension of real enterprise behaviours in matters of investments.

${ }^{11}$ Frequent définitions are FOGAPE (fonds d'aide et de garantie de la PME). BEAC (Banque des Etats de l'Afrique Centrale) of the code of investments and of the ministry of finance. Fogape is a reputed Cameroonian SME, all individual enterprises or collective no matter the judicial form art. of degree $n^{\circ} 84 / 510$ of 13 June 1984 referring to the creation and organization of FOGAPE: $51 \%$ at least of the capital and the managers Cameroonians. The business turnover inferior or equal to 1 billion FCFA (or 1524490 euro). For BEAC by SME it must comprise all enterprises of which (art.5 of decree MINFI n ${ }^{\circ} 244$ of 5 April 1989): Majority of capital and the mangers are nationals; the business is inferior or equal to 500 millions FCFA (or 762245 euros). The definitions of investments code and of the ministry of Finance depend on the same criteria as well as previous definitions but having different breakeven.

${ }^{12}$ We were based on the following exchange rate: 1 euro $=655.957 \mathrm{~F} \mathrm{CFA}$.
} 


\begin{tabular}{|l|c|c|}
\hline Metallurgical & 3 & 5 \\
\hline Plastic Industry & 3 & 5 \\
\hline Material Fabrication & 2 & 3,4 \\
\hline Services Industry & 3 & 5 \\
\hline & $\mathbf{6 0}$ & $\mathbf{1 0 0 \%}$ \\
\hline
\end{tabular}

\section{Internal source}

There are four principal sectors in our sample: general trade, agro-food industry, commercial services and paper and carton industry. The above sectors represent about $69,8 \%$ of all commercial, industrial and services SME of our study. However, our sample is lightly over represented in the agro-food industry, a developed sector that is heavily competitive. The aim of studying is SME's that are located in the city of Douala is triple (Nkalou, 2001, Beyina 2003, Ndong Ntah 2004): The first advantage is linked to the fact the study is carried out in the city of Douala which is the economic capital of Cameroon. It regroups principal ports activities, railways and air services of the Country. The second advantage is the heavy density of SME in the city hence the analysis of funding problems allows for effective authentication or non authentication of massive resort to indebted SME. Lastly, the choice of Douala as field of analysis allows us to better understand the behavior of SME managers when confronted to funding. We took a census of SME list that constitute the mother population of our investigation. The mother population is composed of 180 industrial SME and commercially patronized adhering organizms, Promote, cretes and Pro-SME ${ }^{13}$ which is a Canadian promotion SME in Cameroon. On the basis of this mother population, we constituted a sample of 70 SME of industrial, commercial and assimilated activities among which sixty SME replied to our questionnaire.

\subsection{Research Hypothesis}

Our reflexion relies on conclusions of synthesis and analysis of studies on access to SME in different funding sources. Conclusions of these studies does not allow for the confirmation of the existence of discrimination of funding offered to SME (Julien, 1994; Homes \& KENT 1990, Balavin and al. 1994; Wtterwulghe, 1995). Furthermore, different authors seem to agree that SME have advantage to resort to short-term indebtedness. Short or long term indebtedness must be mastered; and mastered indebtedness is neither excessive nor insufficient( Cieply, 1997; Oloua, 2007). A mastered indebtedness supposes a healthy financial structure and this would be based on a balanced existence between personal funds and debts. It is not enough to simply envisage high leveled debt. What matters is to consider the positive impact that the indebtedness gear stick can exert. In this case, a level of mastered indebtedness refers to two situations: either it is equal to the optimal rate of indebtedness defined by the enterprise and that corresponds to the financial structure that is permanent to this in order to maximize its net value $\mathrm{e}^{14}$; or it corresponds to an optimal indebtedness capacity, or a liability structure beyond which the borrower refuses to grant new funding ${ }^{15}$. The importance of volume of these bank indebtedness forms have been observed in the balance sheets of SME, but they might appear to be inefficient in the funding of investments. If the thesis in favour of renewing short-term loans for funding investment projects can turn around delay obstacles (short), it seems to ignore negative incidence of high financial charges incurred on expected performances of investment to realize. Anywhere, the problem of funds still exist; because the lack of long bank funding in the Cameroonian context or the insufficiency in the financial structure of SME does not allow SME to benefit

\footnotetext{
${ }^{13}$ Pro-SME: Cameroon organization for promotion Cameroon

${ }^{14}$ This means that a financial market is existing and the possibility to have access to it. In this situation, the optimal indebtedness rate can be defined as one that permits the enterprise to maintain its financial autonomy and growth without losing profits (Paranaque Cieply, 1997); it equally raises the problem of cost linked to indebtedness.

${ }^{15}$ The problem of SME bank debt resides on its composition. Let's admit that one of the argument is not in favour of bank indebtedness and of its growth be the saturation of this indebtedness at the optimal level, it would appear that almost all the total debt is composed of short-term loans and current bank contests (CBC) which does not allow long last risked investment.
} 
from positive gear stick of bank indebtedness. All of these analyses leads us to the first hypothesis (H1) of this study which is: "bank indebtedness adapted to the needs of SME and well mastered by its managers (deciders) can permit SME to fund, make profit and realize durable investments above the balance sheet". These analyses come out with two types of problems of bank indebtedness of the SME: the problem of volume and quality. Now, one of our objectives is to show that actual characteristics of bank indebtedness in the Cameroonian context of volume and quality does not facilitate the realization of funding of investments and form the performance of SME stand point or otherwise from the point of view of volume and quality, bank indebtedness of the SME does not allow the later to develop, realize and to fund his investments from which the first under hypothesis (H1.1), "the quality of bank offer towards Cameroonian SME can be an obstacle to the realization of investments to these enterprises" In effect, the conditions of bank offer translates the quality of SME bank indebtedness. Inadequacy between funding needs expressed by SME in the framework of investments notably and funding really obtained. This inadequacy is equally observed between the level (or volume) of funding solicited by SME and the level of funding offered by banks. In other words, SMEs are poorly funded by banks and consequently badly indebted; because banks grand only short-term loans and scarcely in the proportions and conditions desired by SME. This bad indebtedness which poses the problem of quality cannot really allow SMEs to realize the desired performances where the second under hypothesis (H1.2) steps in as: "the weak level of bank indebtedness of Cameroon SME leads to weak performances in the said SME and can be a handicap to the funding of their investments". In effect, the balance sheets of Cameroon SMEs rarely present long and medium term bank loans. When it is the case, they are debts of small amounts. Thus, the level of bank debts i.e.: long and medium terms of the SME are relatively weak. As consequence the SME cannot really benefit from a gear stick of financial profitability. The same in the global level, when SME bank debts are weak, it will have an unfavourable incidence on the choice and the funding of investments. This will raise the question of finding a strategy of funding which is adapted to Cameroon SME showing the importance of the second hypothesis (H.2) of our study: «funding strategy based on appropriate funding modalities (of type informal risk capital) that can contribute to the decision of the best choice of investments and to the profitability of Cameroon SME. These two hypotheses and the sub hypothesis that we have announced form the core of our study. Elaborated from research documentary, this core of hypotheses in relief with principal objectives of the research and constitutes the core of the systematic investigation from which the results will be presented. In total, several questions (hypotheses) are reattached to the funding problem and to the choice of investments that regroups interrogations on the two principal structures of the funding of Cameroon SME which are: formal funding structures essentially characterized by banks and the informal funding structures characterized by group savings.

\section{Questions related to formal funding structures}

It is concerned with resorting to bank indebtedness ; and questions related to this mode funding have been written with inspiration from the works of authors such as : Renfrew (1982); Calof (1985), Holmes and Kent (1990) ; Dunstan and al. (1992); Baldwin and al. (1994) ; Wtterwulghe (1998) ; Bekolo-ebe (1986) ; Yondo (1986), Attouch (1986) ; Lelart (1985) ; Chandarvakar (1988) ; Suret and Arnoux (1995) ; Donatien eze (2001) ; UM M.T. (1996); Bessiere, V. \& Stephany, E. (2014); Dufourcq, N. (2014); Adair P., Adaskou M. (2011); ADAIR, P.(2011).

\section{Questions related to informal funding structures}

Questions related to informal funding structures resort essentially on the works of G.A. Brenner, H. Fouda, J.M. Toulouse (1990). (Informal saving groups and the creation of enterprises in Cameroon); M. Lelart (1990) "parallel funding circuits: state of the question", Bekolo-ebe, Bilongo (1990), (Benefit behaviour and 
structures of interest rate in informal saving groups); Hugon (1990); Non institutional finance: expression of development crisis); Hermandez (1995) (logic of enterprise management in the informal sector); Bloy, Dupuy (1990), (Adaptation of management rules with constraints of informal funding); Haudeville (1990); (Informal saving and funding of productive enterprise); Servet (1990), (Representation of currency and saving backups and limits of informal mobilization of saving); Fouda and Brenner T. (1990,1993) (Funding of Bamiléké enterprises in Douala); Pairault, T. (1990, 1993), and Kemayou (2011) (SME banks and funding of informal saving groups; Tioumagneng, A. (2012).

\section{3- Funding Of Investments In Sme And Objective Divergence In Financial Criteria Of The Choice Of Investment.}

3-1. Funding of investments of Cameroon SME: resorting to indebtedness.

Here we want to present some results of the investigations that we carried out in Cameroonian SME. Thanks to flat selections and test associations, we were able to arrive at a certain number of conclusions.

\subsubsection{Indebtedness of Cameroon SME}

Let us recall that the financial literature has longtime looked for a way of measuring the indebtedness virtues "Modigliani and Miller had shown that indebtedness in the absence of imposition, was acting on the value of the firm (1958) but that this neutrality was disappearing in the presence of imposition (1963). In the last case, indebtedness was the creator of value (1963). Other actors, have shown that indebtedness can be considered as signal (Ross, 1977) or as a means of pressure on managers (Jensen, 1986). The reverse of actors such as Altman (1968, 1984), Collongues (1977), Gilson (1989, 1990) or Wruck (1990) shows that excess of indebtedness is the generator of bankruptcy, of direct and indirect costs. The influence of indebtedness on profitability is conditioned by a series of factors such as the economic context (Pratt and al.; 1994), property structure (Charreux, 1987), capacity and reputation of the manager (Pigé, 1997) or the activity sector (Titman and Opler, 1999; Oseo, 2006). Indebtedness in Cameroon is an important variable in the life of the SME (Um Nguem, 1997; Beyina, 2007). The theorical approach of the indebtedness phenomenon of SME in Cameroon has known significant developments. These developments have brought in new thoughts on the three essential questions that emerge naturally of the study of the relation between indebtedness and funding of Cameroon SME. The first question is to know how and why we are indebted, especially why the Cameroonian SME is indebted. The second question is concerned with the characteristics of indebtedness of Cameroon SME in other words, what is the structure of the debt of the Cameroon SME? The third question is to know at what price the Cameroon SME is indebted to finance its investments, the reasons of indebtedness (why and how?).

\section{-Why are Cameroonian SMEs indebted?}

There are two final reasons to know why Cameroon SMEs are indebted: indebtedness is either a normal function of the SME service, or the exceptional operations service (investments) in the life of the SME. In other terms, the Cameroonian SME resort to indebtedness in order to finance its activities: funding linked with exploitation of activities and especially investment activities.

\section{-How are Cameroonian SME financed?}

It would be a matter of examining the funding modes used by Cameroon SME for the past four (4) years, characteristics of interest rates and the evolution of financial charges.

\subsubsection{Funding modes}

Cameroon SMEs resort to several funding modes, but the table below indicates certain funding modes are massively sollicitated in a permanent manner: 
Table $n^{\circ}$ 2: Funding modes of $60 \mathrm{SME}(\%)$

\begin{tabular}{|l|c|c|c|c|c|c|}
\hline & NA & Not at all & A little & Averagely & Many & Total \\
\hline Auto funding (91.101) & 5,00 & 31.67 & 26.67 & 16.67 & 20.00 & 100 \\
\hline Saving (91. 102) & 3,33 & 33,33 & 38,33 & 20,00 & 5,00 & 100 \\
\hline Informal saving (91.103) & 8,33 & 10,00 & 11,67 & 46,67 & 23,33 & 100 \\
\hline Association (91.104) & 16,67 & 41,67 & 25,00 & 15,00 & 1,67 & 100 \\
\hline Loan (91.106) & 6,67 & 13,33 & 16,67 & 43,33 & 20,00 & 100 \\
\hline Cooperative (91.106) & 6,67 & 80,00 & 5,00 & 5,00 & 3,33 & 100 \\
\hline Others (91.107) & 8,33 & 61,67 & 18,33 & 10,00 & 1,67 & 100 \\
\hline
\end{tabular}

\section{Internal source}

We note that the funding modes mostly sollicitated by Cameroonian SMEs are : informal saving and bank loan ; 46,67\% resort averagely to informal saving and 43,33\% resort averagely to bank loan ; 23,33\% resort in a great number to informal saving and $20 \%$ resort to bank loan. The component diagram and factorial graphic below equally confirms.
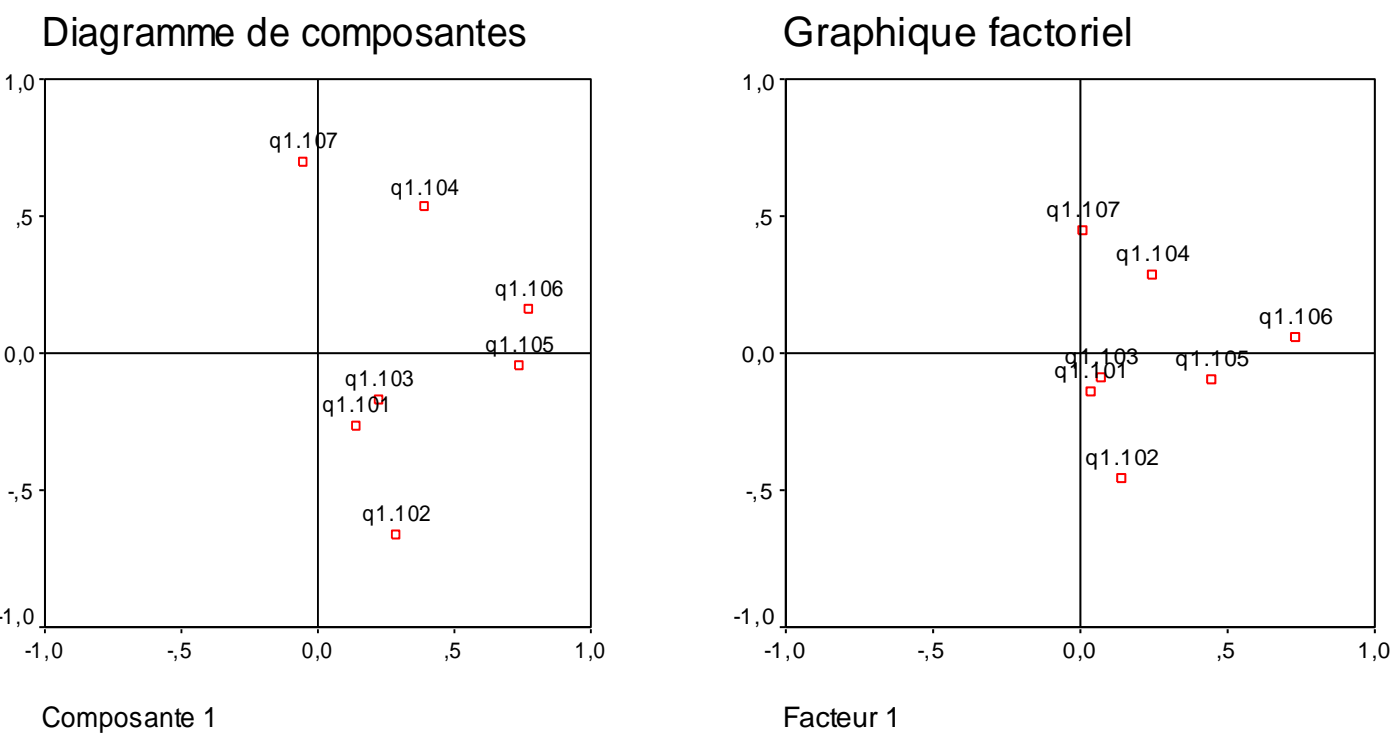

Results of the investigation indicate that: q1105 and q1103 are very closed to abscises axis and this explains notably the resort of SME as a priority to these two funding modes. Moreover, in terms of importance, bank loan comes in the second position after informal saving. This low level of bank indebtedness as compared to informal saving constitutes a handicap to SMEs that have sollicitated this mode of funding because funding of investments requires heavy financial means (H1.1).

Dendogram of funding modes 


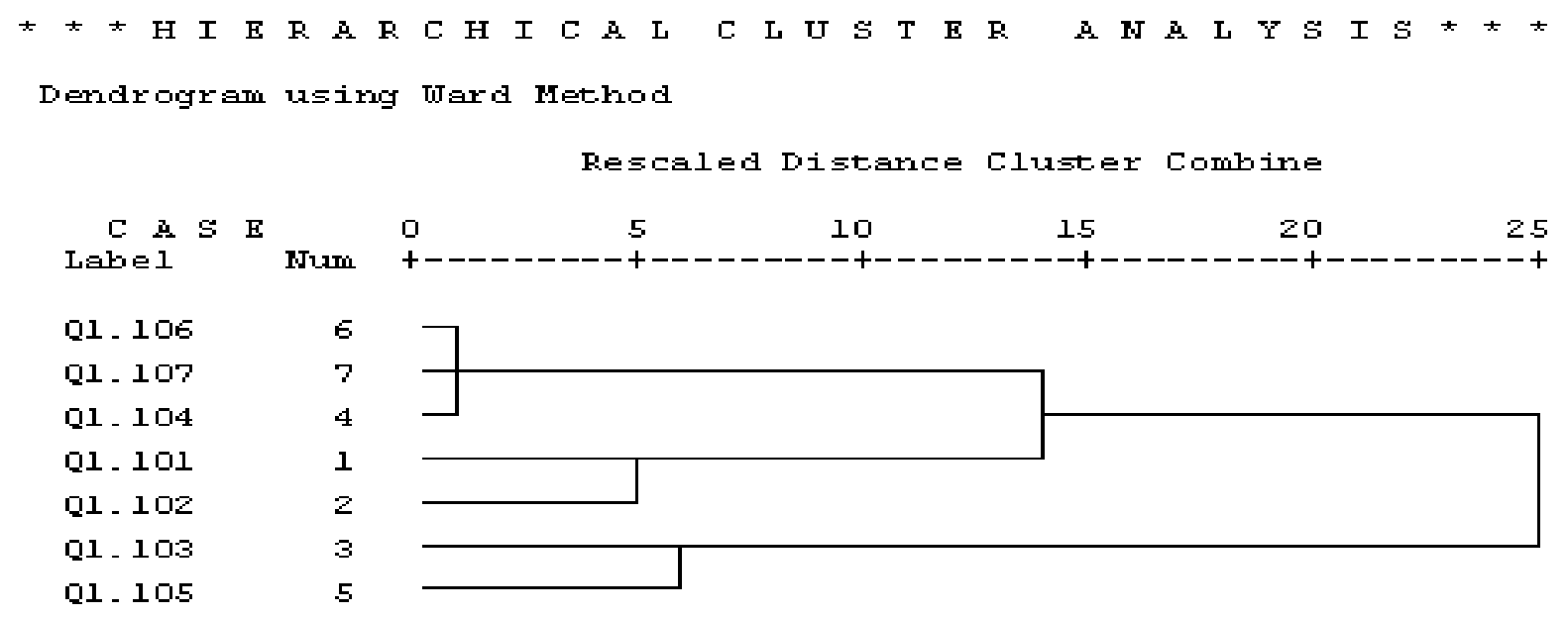

Dendograms, component diagram and factorial graphic of funding modes above principally confirms resort of Cameroon SMEs to these two modes of funding. In reading these results, they indicate that Cameroon SMEs resort massively to indebtedness (formal and informal: informal saving and banks). This resort to bank funding and informal saving is expressed notably by the influence of their personal capital. The results of investigated SMEs indicate : 31,67 \% SMEs do not have personal capital, 26,67 \% resort a little to their personal funds because of its weakness, $16,67 \%$ SMEs resort averagely to their personal capital which is still insufficient ; $20 \%$ of SMEs resort largely to auto-funding. Finally, in order to finance their activities, Cameroon SMEs resort to informal saving in priority; and the reasons are multiple: insufficient capital, low level of bank indebtedness which is a serious handicap for the choice of funding investments.

\subsubsection{Characteristics of interest rates, evolution of financial charges}

Resort to bank funding and especially informal saving distinguishes itself from other modes of funding as well as financial charges derived from it, "khi-deux tests", the correlation tables (see methological annex) indicates and confirms.

$\underline{\text { Table }} \mathbf{n}^{\circ} \mathbf{3}$ : Khi deux tests

\begin{tabular}{|l|l|l|c|}
\hline & \multicolumn{1}{|c|}{ Value } & Dd1 & $\begin{array}{c}\text { Symbolic significance } \\
\text { (bilateral) }\end{array}$ \\
\hline Person's khi deux & $\mathbf{1 9 9 , 3 5 4 ~ 2 4 9}$ & 48 & $\mathbf{5 , 2 2 6 3 E - 0 8}$ \\
\hline Probability report & $\mathbf{1 3 3 , 7 2 1 5 5 3}$ & 48 & $5,1513 \mathrm{E}-10$ \\
\hline Linian by lineas association & $\mathbf{1 1 , 9 6 9 7 7 4 6}$ & 1 & 0,0005407 \\
\hline Number of valid observations & 149 & & \\
\hline
\end{tabular}

56 units $(88,9 \%)$ have a theorical number inferior to 5 . The minimum is from, 03.

In the above table and thanks to khi deux test, we have double breasted the rate variable and the funding mode variable. The critical probability is equal to zero; Therefore, inferior to $5 \%$. This confirms effectively the hypothesis that the rate variable influences the funding modes (banks and informal saving) significantly even in the breakeven of $1 \%$. The rate of loan therefore depends on the funding source and the nature of loan. Concerning bank loan, the rate is about $20 \%$ (Beyina, 2007). This rate can reach 30 and $40 \%$ monthly for informal funding by group saving (Beyina, 2007, Um, 1994, Nkakleu 2003) or even go above this breakeven. The impact of charges linked to different rates applied is therefore considerable. In summary, the result obtained here confirms the hypothesis that SMEs resort massively to indebtedness ${ }^{16}$. Despite high cost of indebtedness (cf supra khi deux test), these SMEs prefer to continue to indebt. We must however recall

${ }^{16} 51,30 \%$ for informal saving and $22.08 \%$ for bank loan (Beyina, 2007). 
that indebtedness whether formal or informal involves heavy financial charges as well as difficult conditions of access.

\subsubsection{Conditions of access to bank funding}

Contrary to informal structures of funding that presents a certain suppleness in the conditions of access, access to formal bank funding is submissive to certain obligations and constraints which even when fulfilled does not guarantee the sollicited grants especially when you are considered as risk customer the following table presents the guarantees supplied by investigated SMEs and other conditions of access to indebtedness.

\section{Table $n^{\circ}$ 4: Access conditions to indebtedness}

\begin{tabular}{|l|c|c|c|c|}
\hline & NA & YES & NO & TOTAL \\
\hline Personal contribution & 15,00 & 75,00 & 10,00 & 100 \\
\hline Mortgage & 10,00 & 51,67 & 38,33 & 100 \\
\hline Profitability project & 11,67 & 83,33 & 5,00 & 100 \\
\hline Life insurance & 13,33 & 50,00 & 36,67 & 100 \\
\hline Solvency & 25,00 & 68,33 & 6,67 & 100 \\
\hline Others & 33,33 & 31,67 & 35,00 & 100 \\
\hline
\end{tabular}

Internal source

Concerning guarantees furnished during the period of bank loan, the SMEs that have sollicited bank funding are generally offended by the quality of bank offer which are rather harsh conditions to indebtedness access (H1.1). In total, resorting to bank indebtedness is in function with the guarantees brought and especially the conditions to access this mode of funding. In addition to difficult access conditions, banks grant only shortterm loans and scarcely in the exact proportions and the desired conditions of the SMEs.

\subsubsection{Resorting to new loans}

Despite the cost of indebtedness whether formal or informal, investigated SME prefer to continue taking further debts. Results obtained from 60 Cameroon SME are regrouped in the following table.

\section{Table $n^{\circ}$ 5: New loans envisaged by SMEs (\%)}

\begin{tabular}{|l|c|c|c|c|}
\hline & NA & YES & NO & TOTAL \\
\hline NEW LOAN & 0.00 & 86.67 & 13.33 & 100 \\
\hline
\end{tabular}

Internal source

Cameroon SME investigated prefer all of them to continue to indebt themselves $(86.67 \%)$. All of the problem relies on the adaptation of this indebtedness to the needs of the SME and mastery of the managers. In sum, indebtedness (bank or informal saving) adapted to the needs of SME and well mastered by managers allow the later to finance and to realize chosen investments. With regards to high cost of the two funding modes usually sollicited by SMEs, the question of research of a funding strategy adapted to the real needs of the chosen investment funding in these structures remains.

\subsection{Divergence of objective in the financial criteria of the choice of investment.}

- Cameroon SMEs, ANV, and recuperation delay of capital: choice of the recuperation delay as criteria of decision (elements of economic crisis).

Concerned with trying to know if the financial criteria of the choice of investments employed by the investigated SMEs care about maintaining a sufficient level of liquidity in the enterprise, we gathered the following results below. 
$\underline{\text { Table } n^{\circ} \text { 6: }}$ Preferences between ANV and recuperation delay

\begin{tabular}{|l|c|c|c|c|c|}
\hline \multicolumn{1}{|c|}{ ELEMENTS } & ANV (1) & $\%$ & RDIC (2) & $\%$ & Total (\%) and qty) \\
\hline SME investigations & 10 & 0.16 & 50 & 0.84 & 60 \\
\hline TOTAL (\%) & & 0.16 & & 0.84 & 100 \\
\hline
\end{tabular}

Internal source

(1) ANV : Actual net value

(2) RDIC : Recuperation delay of invested capital

From 60 SMEs, investigated $16 \%$ resort to ANV for choice of investments and 84 prefer the recuperation delay of capital invested as decision criteria. The investigation reveals two types of criteria as decision aids: recuperation delay and the actual net value. Recuperation delay is mostly used while the actual net value is generally reserved for particular investments according to investigated SMEs. It is used for strategic and long-term. With the ANV criteria, the decider pursues the objective of maximizing profit. The aspect of risk illiquidity is totally absent of the criteria that lead more often to favour heavy investments when considering initial capital contribution that brings out important mass cash flows. Recuperation delay, being criteria of extreme prudence, the actual net value allows for reporting global profitability of an investment in its total duration and life. Each type of criteria responds perfectly to the rationality of the decider to whom reference is made (rationality, optimizing and exploratory). In practice, the entrepreneur passes from the ANV criteria to the recuperation delay if the variations of the economic environment of enterprise necessitates accrued prudence (Lambert, 1998) the inexistence of criteria "intermediary" reflects a theorical lack that has to be filled by methods of choice sensible to maximization of profit and to minimization of risk of illiquidity at the same time. The SME study finally shows that elements of economic crisis constitute major explanatory factor of investor's carefulness. Pure financial state (lack of personal funds, exclusive indebtedness) was often secondary in the SME investigation. The principal slow down to investment originates from economic crisis, an uncertainty which does not depend on SME. The results of investigated SMEs reinforce the idea of a direct link existing between the exigency of a rapid come back of invested SME liquidity in the city of Douala and the economic uncertainty that is weighing on the enterprise (price of cereals, technology and demand). Elements of financial constraints are not left out. However, it is noted that the principal motivation in the choice of investment criteria is dictated by the degree of uncertainty in the economic environment. In this context, the choice of the criteria of the recuperation delay is justified if short term financial constraints exist in the enterprise and or economic uncertainties that weighs on the investment.

\section{Informal Capital As Alternative Mode Of Funding For Investment Decision. 4.1 The phenomenon of informal saving: African informal saving}

Informal saving structures observed in about forty African countries are mutual savings, turning around or rotated saving and loan associations. They are widely spread within the entire population. In African countries, they drain considerable and an important capital source. These structures have existed for a long time now and have deepened their roots in long time history of the people concerned ${ }^{17}$. African informal saving and loan structures are all based on the same principles but their variables are numerous and

\footnotetext{
${ }^{17}$ In France, peasants had the habit of working together in the farm; or repair the roofs of houses together and each of them had his or her turn. African peasants were doing the same at their own end. They formed work groups informally and naturally. When money started stretching out, they organized informal financial saving groups to meet challenges such as funeral expenses, or bride prices.
} 
endless $^{18}$. Each investigation carried out on the field here and there gives a new form, and each monography has something particular or something ignored. This variety is evidence of the multitude of local names ${ }^{19}$.

\subsection{The informal saving and loan as an alternative funding mode to banks.}

To meet with challenges of insufficiency of banks granting loans, other means of funding have been developed. It is funding through informal saving and loan structures (Aryeetey, 1998, Mayoukou, 1996) and more and more of the micro-finance (Bousseta, 2001). These two funding sources constitute what is called today "Decentralize Financial System»(DFS). In effect, decentralized financial institutions through proximity relations with customers allows for the creation of mechanisms of confidence. Micro-loan institutions have succeeded in many developing countries. In Bangladesh for example, the Grameen bank ${ }^{20}$ sprung from the microfinance. In Bolivia, the "Bancol", specialized in microloan has become the second bank in that country ${ }^{21}$. Success of these microloan-establishments results notably from mechanisms of solidarity guarantee put in place. These institutions usually give loans to groups of entrepreneurs who are responsible for the reimbursement of loans by each of the members. Apart from the solidarity mechanisms put in place, the success of microfinance institutions has been proximity links (Labie, 1998). The expansion of saving and loan cooperatives started rapidly in 1990 as result of multiple economic crises. In this context of under development, of microfinance, the Cameroonian entrepreneur is obliged to constitute a saving in order to finance his investment project. More often, he calls on the informal institution to assist him constitute a saving ${ }^{22}$. The Cameroonian entrepreneur is confronted to risk or short comings in this choice alternative. The challenge consists in developing efficient funding strategies, and one, of them concerns the resort to risk capital in informal finance.

\subsection{Informal saving risk capital: $a$ new and modern helping tool for investment decision.}

Risk capital is a funding mode of the enterprise in the creation and developing stages. It constitutes a contribution of personal funds implicating risk sharing and opportunities between the enterprise and the financial partner. It is based on long-term relation through which the Investor's objective is to realize more value or reach certain socio-economic objectives. The funding mechanism of risk capital permits a reduction of agency problem between investors and entrepreneurs and through its suppleness, it considers the needs of the enterprise in function of its state of development and evolution of the level of risk. In this case, the choice of investment can guarantee operation decision. Risk capital accompanies ad hoc innovations notably: decisional, financial, managerial, organizational etc. It is combined with a follow up or partnership (Etoundi, 2003). Two principal structures characterize the financial landmark of Cameroon: formal funding structures and the informal funding structures. It is necessary to find a funding strategy that allow funding structures themselves and SMEs to minimize risks incurred, develop serious partnership and an efficient rationality criteria, success and development. We think of risk capital as informal funding structures adapted to local realities. More than $73 \%$ of investigated SMEs are strongly interested in this initiative.(H2.) They would voluntarily accept to participate to the capital of their enterprise; and the management of financial flows granted would allow for a new perception in the choice of investments to be made in the SME. In the framework of this article, we are proposing a funding model by risk capital (informal funding) adapted to

\footnotetext{
${ }^{18}$ In Benin, adjoulou means to work in the farms, gbé or so means to contribute for a family or so means to contribute for a family or religious ceremony. In Congo, Denké means to dig a grave.

${ }^{19}$ In some countries we find tenths of different roots corresponding to many dialects as possible. The same words are found in each side across the boundary. This is justified by the origin of these associations. We find the same terms from one country to another.

${ }^{20}$ Founded in 1980 and that funds micro projects for amounts beginning from 30 to 50\$ US. This institution today counts more than 2,2 million customers for a reimbursment rate which is equal to $98 \%$.

${ }^{21}$ (BOUSSETTA, 2001)

${ }^{22}$ It allows the entrepreneur to escape from a sort of solidarity tax deriving from redistributive pressure on revenues exerted by the community. The entrepreneur aqually faces challenges of personal propension and expenses (MAYOUKOU, 1994).
} 
choice and to the funding of SME investments. We think they can bring in solutions to rationality problems, choice decision and investment profitability in the long-term.

\section{Conclusion}

Results obtained from investigated SMEs reveal two types of criteria of decision aid: recuperation delay and the actual net value. The study shows that the criteria mostly used is the recuperation delay while the actual net value (ANV) is reserved for particular investments of strategic and long-term nature. With (ANV), the decider's objective is to maximize profit. Illiquidity risk aspect is absent even though it favours heavy investments involving a mass of important cash flows. Actual Net Value renders account on global profitability on investment in duration of life. Each criteria perfectly responds to decider rationality to which reference is made (optimist rationality and exploration). If an enterprise does not have access to bank loan in order to finance his investments, as a Cameroon SME, it should go out for choice risk guided by available means of funding. The only efficient alternative is funding by informal risk capital ${ }^{23}$ which is adapted to suit an enterprise in the creation and developing phase. It involves the contribution of personal funds and sharing of risks and opportunities between the enterprise and the financial partner. It is subscribed under long-term relation in which the investor's arm is to achieve socio-economic objectives and realize more value. The suppleness of the mechanism by informal capital risk allows for a reduction of agency problem between and entrepreneurs while taking into account the needs of the enterprise in function of the state of development and evolution of the level of risk. This can guarantee operation and decision in the choice of investments.

\section{References}

[1] ADAIR P., ADASKOU M. (2011) «Théories financières et endettement des PME en France, Une analyse en panel », Revue internationale P.M.E., Volume 24, numéro 3-4, 2011, p . 137-171.

[2] ARROW K. [1956], «Le rôle des valeurs boursières pour la meilleure répartition des risques », EconométrieCNRS, p. 41-48.

[3] ALTMAN E. (1984), "A Further empirical investigation of the bankruptcy cost question", Journal of finance, vol. XXXIX, n 4. p. 1067-10S9

[4] ARYEETEY, E. [1998], "Informal finance for private sector development in Africa" Economic research papers, $n^{\circ} 41$, Banque Africaine de développement.

[5] ATTOUH Michel [1986] «L'économie camerounaise peut-elle être considérée comme une économie d'endettement ? », revue camerounaise de management, $\mathrm{N}^{\circ}$ 3-4juillet-Août septembre 1986 pp 127-160.

[6] BABUSIAUX D. (1990), Décision d'investissement et calcul économique dans l'entreprise , Paris, Economica.

[7] BALDWIN J. W., C. CHANDLER et T. PAPAILIADIS (1994). Stratégies de réussite profil des petites et moyennes entreprises en croissance (PMEC) au Canada, Statistique Canada, $\mathrm{n}^{\circ}$ 61-523R F, hors-série.

[8] BANCEL F., RICHARD A. (1995), Les choix d'investissement, Paris, Economica.

[9] BEKOLO-EBE B. [1986] «Systèmes des tontines : liquidité, intermédiation, comportement d'épargne », Revue d'économie politique.

[10] BEKOLO-EBE, BILONGO, R. [1990] «Comportements des gains et structure des taux d'intérêt dans les tontines : étude de quelques cas », Ed. AUPELF-UREF, Paris, 1990.

[11] BESSIERE, V. \& STEPHANY, E. (2014). Le financement par crowdfunding: Quelles spécificités pour l'évaluation des entreprises ?. Revue française de gestion, 242,(5), 149-161.

[12] BETBEZE, J. (2014). Financer les PME en France : encore un « papier »!. Revue d'économie financière, 114,(2), 31-38.

[13] BEYINA E. (2009), « le financement par capital risque dans les PME innovantes : le cas spécifique des PME innovantes camerounaises » Innovations, $\mathrm{n}^{\circ} 29$, pp.169-195.

[14] BOUSSETTA M. [2001] "Contrainte financière des micro et petites enterprises et nouveaux modes de leur financement au Maroc", Revue Congolaise de Gestion, n4-5, pp. 30-50.

\footnotetext{
${ }^{23}$ Risk capital of informal saving may lead to the creation of micro credit institution in which the success results notably from guaranteed mechanism put in place. In effect, this institutions belong to group of entrepreneurs who are responsible for the reimbursement of debts by each member.
} 
BRENNER, G.A., FOUDA, H. et TOULOUSE, J.-M. [1990b] «Les tontines et le création d'entreprise au Cameroun » dans L'entrepreunariat en Afrique francophone : culture, financement et développement, Hénault et M'baret, Aupef/Uref/Eurotext, pp.97-105.

[16] CALOF J. [1985] « Analysis of small business owner's financial preferences, Journal of small Business and Entrepreneurship, 1985, vol.3, n³.

[17] CHARREAUX, G. [1985] «Le dilemme des PME : ouvrir son capital ou s'endetter », Revue Française de Gestion, janvier-février. pp. 59-73.

[18] CIEPLY S., PARANQUE B. [1998] "Le rationnement des petites entreprises sur le marché du crédit: Mythe ou réalité ? », Revue banque et marché, 1998.

[19] COLLONGUES Y. (1977), “Ratios financières et prévision des faillites des PME”, Revue banque.

[20] Dietsch, M. \& Mahieux, X. (2014). Comprendre le déficit de financement des PME pour stimuler leur croissance. Revue d'économie financière, 114,(2), 17-30. doi:10.3917/ecofi.114.0017.

[21] DEBREU G. [1959], The theory of value, Yale University Press.

[22] DUFOURCQ, N. (2014). Le financement des PME : un enjeu de compétitivité. Revue

[23] d'économie financière, 114,(2), 39-54.

[24] DUPUY, C., BLOY, E. [1990] «Adaptation des règles de gestion aux contraintes du financement informel », Ed. AUPELF-UREF, Paris, 1990.

[25] ETOUNDI C. (2003), Analyse de l'impact d'un financement par capital risque sur la contrôlabilité de la PME: cas de Cenainvest SA et 18 PME camerounaises ', 8es journées scientifiques du réseau entreprenariat de l'agence Universitaire de la Francophonie, Université de Rouen.

[26] FISHER I. [1930], The theory of interest, MacMillan.

[27] GILSON S. C. (1997), "Transactions costs and capital structure choice Evidence from financially distress firms", Journal of Finance.

[28] GUILLE M., [1994] "Savoir bancaire spécifique, marché du credit et intermediation financière", Revue d'Economie Appliquée, Tome XLVII, (4), pp.49-78.

[29] HAUDEVILLE, B. [1990] "Epargne informelle et financement de l'entreprise productive", AUPELF-UREF, Paris, 1990.

[30] HERNANDEZ Emile-Michel [1995]: La logique de gestion de l'entreprise du secteur informel, revue française de gestion, Avril-Mai 1995. pp66-75.

[31] HOLMES S. et P. KENT (1990), "An empirical analysis of the financial structure of smalland large australian manufacturing enterprises", $5^{\text {th }}$ National Small Business Research Conference, Toowoomba, Queensland.

[32] HUGON, P. [1990] «Le secteur non structuré ou informel des économies des pays du tiers monde », Problèmes économiques, 1980.

[33] JAFFEE D. et STIGLITZ J. [1990], «Credit rationing », dans B. FRIEDMAN et F. HAHN (ed), Hand book of Monetary Economics, 2, Elsier science, pp. 83-88

[34] JENSEN M. C. (1986), "Agency costs of free cash flow, corporate finance, and market of takeovers", American Economic Review.

[35] JULIEN R A. (1994), Les PME, Bilan et perspectives, Economica, GREPME (groupe de recherche en économie et gestion des PME), Paris.

[36] KEMAYOU L.R., GUEBOU F., MADIBA . M. S. (2011) «Tontine et banque en contexte camerounais », La Revue des Sciences de Gestion, vol. 249-250, no. 3, 2011, pp. 163-170.

[37] KNIGHT F.H. [1921], Risk, Uncertainty and profit, Harper and Row.

[38] LABIE M. [1998], «La gestion de proximité : une condition essentielle des mécanismes de garanties solidaire », ADA Dialogue, numéro 12-1/98.

[39] LAMBERT, G. [1988] "Choix d'investissements: un nouvel outil de gestion", Revue Française de Gestion, avril mai, $n^{\circ} 68$.

[40] LAMBERT, G. et ROMELEAR, P.[2001] « Décisions d'investissement et rationalités » Ed. Vuibert pp. 169227.

[41] LELART, M. (dir) [1990] «La tontine. Pratique informelle d'épargne et de crédit dans les pays en voie de développement », Aupelf/Uref, John Libbey Eurotext.

[42] LEPAGE F., COUDERC JP. et PERRIER JP. (2014) «Determinants of investment decisions in dairy farms. An approach using the governance theory", Revue française d'économie et de sociologie rurales, ISSN 0013-0559, $\mathrm{N}^{\mathrm{o}}$. 341, 2014, mai-juin 2014, p. 06-24

[43] LINTNER J. [1965], « The Valuation of Risk Assets and the selection of Risky Investments in Stock Portfolio and Capital Budgets » », The Review of Economics and statistics, Février, p. 13-37.

[44] MAYOUKOU C.[1994], «Le système des tontines en Afrique : un système bancaire informel », l'Harmatant, Paris, 144p. 
[45] MODIGLIANI F.; et MILLER M. [1958], « The Cost of Capital, Corporation Finance and the Theory of investment », American Economic Review, juin, p.261-297.

[46] MODIGLIANI E et M. MILLER (1963), "Corporate Income taxes and the cost of capital:a correction", American Economic Review, 53 (3), p. 433-443.

[47] MOUNIA SLIMAN, (2016) «La décision d'investissement en intelligence économique : évaluation et pratique dans les grandes entreprises marocaines », revues Marché et organisations

[48] NDONG NTAH M. [2004], "Informatisation et performance dans la PME au cameroun", Revue Internationale PME, 2004.

[49] NKAKLEU, R. [2001], «Pour une approche contingente des PME au Cameroun. Contribution à la connaissance de l'identité des dirigeants et des modes de gestion du potentiel », thèse de doctorat ès sciences de gestion, Univesité de Strasbourg I.

[50] NKAKLEU, R. [2003, 2004], «Typologie des marchés des PME camerounaises : approches emic versus etic. » 6eme congrès international francophone sur la PME - Octobre 2002 - HEC - Montréal.

[51] OLOUA B. [2007), «Financements et endettement bancaires des PME Camerounaises », Thèse de Doctorat, Strasbourg I (ULP), 2007.

[52] OSEO (2006), «PME et innovation technologique. Pour une relation plus naturelle «, Regards sur les PME, Paris.

[53] PAIRAULT T. (1993), Banques et PME et financement tontinier, in Ponson B. et Schaan J. L., L'esprit d'entreprise : aspects managériaux dans Le monde francophone, John Libbey Eurotext, Ottawa p. 427-446.

[54] PIGE B. [1997] «Le marché boursier réagit-il à l'annonce des changements de dirigeants ? », Revue finance, 1997.

[55] PRATT S.P. et al. [1994], «Valuing small business and professional pratice», Business One Irwing, Homewood. 1994.

[56] UM, M.T. [1996] «Financement bancaire et endettement des PME au cameroun, Thèse de Doctorat, Université de Bordeaux I.

[57] ROSS S. (1977), "The Determination of financial structure: the incentive signaling approach", Bell Journal of Economics.

[58] SERVET, J.M. [1990] «Représentations de la monnaie et des supports d'épargne et limites de la mobilisation de l'épargne informelle » Ed. AUPELF-UREF, Paris, 1990.

[59] SILEM, A. (dir.) [1994], Encyclopédie de l'économie et de gestion, Paris, Hachette Education.

[60] SHARPE W. [1964], «Capital Asset Prices : A Theory of Market Equilibrium under Conditions of Risk », The journal of Finance, septembre, p.725-742.

[61] STIGLITZ, J. HELLMANN, T. [1998]"Credit and aquity Rationing in markets with adverse selection", European Economic Review, August, pp. 281-304.

[62] SURET, J.M. et ARNOUX, L. [1995] «Capitalisation des entreprises Québécoises : évolution et état de la situation, Revue internationale PME, 1995, vol.8, $\mathrm{n}^{\circ} 34$.

[63] TAMARI M. (1980), 'The financial structure of the small firm: an international comparison of corporate accounts in the USA, France, U.K., Israel and japan", American Journal of Small Business, vol. 4, n 4, p. 20-34.

[64] THOMPSON R.A. ; THUESEN J. [1985], « Dynamic Investment Criteria for Capital Budgeting Decisions », The Engineering Economist, vol. 31

[65] Tioumagneng, A. (2012). "Banques et comportement d'endettement des entreprises », Recherches en Sciences de Gestion, vol. 89, no. 2, 2012, pp. 81-99.

[66] TITMAN S., et OPLER T. [1994] "Financial Distress and Corporate Performance", Journal of finance, vol XLIX, n³, 1994.

[67] WRUCK KAREN HOPPER [1990] "Financial distress, reorganization, and organizational efficiency", Journal of Financial Economics, 1990.

[68] WTTERWULGHE Robert [1998] La PME, une entreprise humaine, De Boeck Université, Paris-Bruxelles, $173 p$.

[69] YONDO Marcel [1986] Le financement des PME camerounaises, revue camerounaise de management, $\mathrm{N}^{\circ} 3$ 4, juillet-Août-septembre, 1986, pp 161-174.

\section{ANNEXS}

Dendrogram of interest rate 
Dendrogram using Ward Method

Rescaled Distance Cluster Combine

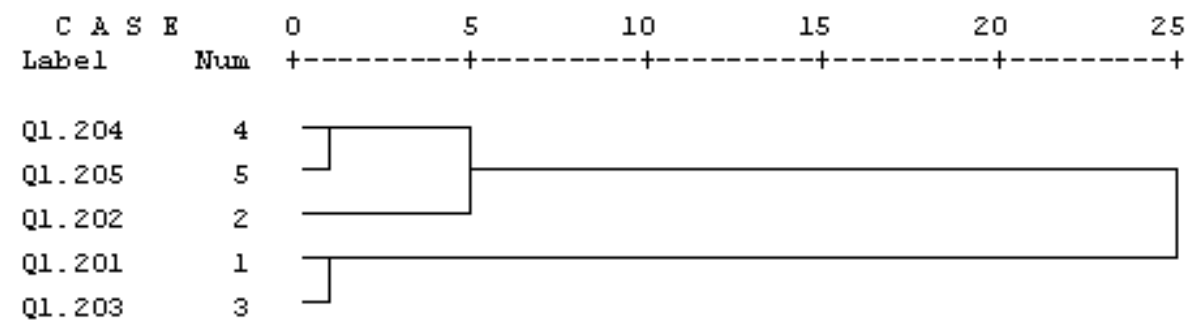

Dendrogramm of financial charges

****H I E R A R C H I C A L C L U S T E R A N A L Y S I S * * * *

Dendrogram using ward Method

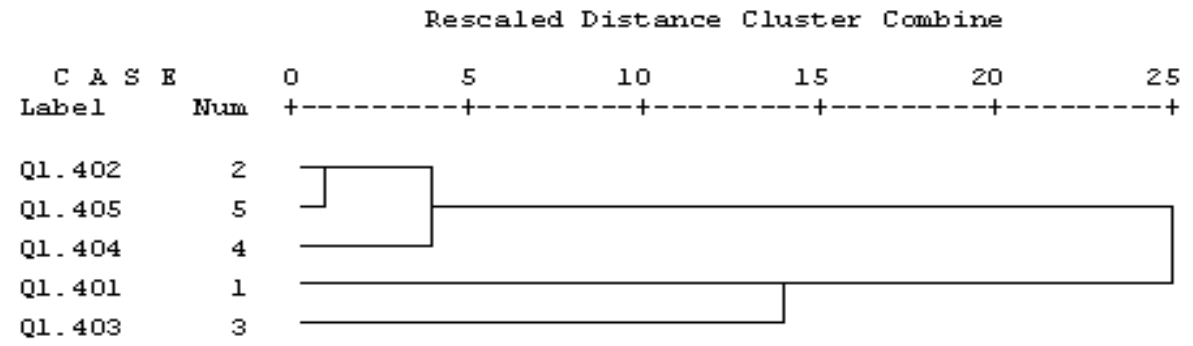

Corrélations

\begin{tabular}{|c|c|c|c|c|c|c|c|}
\hline & & Q2.1301 & Q2.1304 & $\begin{array}{c}\text { Mode de } \\
\text { financement }\end{array}$ & Taux d'intérêt & $\begin{array}{l}\text { Charges } \\
\text { financières }\end{array}$ & Garanties \\
\hline \multirow[t]{3}{*}{ Q2.1301 } & Corrélation de Pearson & 1 & $0,131^{*}$ &,$- 261^{*}$ &, 097 &, 115 &,- 022 \\
\hline & Sig. (bilatérale) & , & ,320 &, 044 & ,459 &, 380 & ,869 \\
\hline & $\mathrm{N}$ & 60 & 60 & 60 & 60 & 60 & 60 \\
\hline \multirow[t]{3}{*}{ Q2.1304 } & Corrélation de Pearson & $0,131^{*}$ & 1 & ,288* &, 110 &,- 209 &,- 125 \\
\hline & Sig. (bilatérale) & ,320 & , & ,026 & ,401 &, 109 &, 340 \\
\hline & $\mathrm{N}$ & 60 & 60 & 60 & 60 & 60 & 60 \\
\hline \multirow[t]{3}{*}{ Mode de financement } & Corrélation de Pearson &,$- 261^{*}$ & ,288* & 1 & ,176 &,$- 279^{\star}$ &,- 225 \\
\hline & Sig. (bilatérale) &, 044 & ,026 & , & , 178 &, 031 & 084 \\
\hline & $\mathrm{N}$ & 60 & 60 & 60 & 60 & 60 & 60 \\
\hline \multirow[t]{3}{*}{ Taux d'intérêt } & Corrélation de Pearson & ,097 &, 110 &, 176 & 1 &,$- 443^{\star \star}$ &,- 120 \\
\hline & Sig. (bilatérale) & ,459 & ,401 &, 178 & , &, 000 & ,363 \\
\hline & $\mathrm{N}$ & 60 & 60 & 60 & 60 & 60 & 60 \\
\hline \multirow[t]{3}{*}{ Charges financières } & Corrélation de Pearson & ,115 &,- 209 &,$- 279^{*}$ &,$- 443^{\star \star}$ & 1 & ,189 \\
\hline & Sig. (bilatérale) & ,380 &, 109 &, 031 &, 000 & , & 148 \\
\hline & $\mathrm{N}$ & 60 & 60 & 60 & 60 & 60 & 60 \\
\hline \multirow[t]{3}{*}{ Garanties } & Corrélation de Pearson &,- 022 &,- 125 &,- 225 &,- 120 & , 189 & 1 \\
\hline & Sig. (bilatérale) & ,869 & ,340 &, 084 & ,363 &, 148 & , \\
\hline & $\mathrm{N}$ & 60 & 60 & 60 & 60 & 60 & 60 \\
\hline
\end{tabular}

${ }^{*}$. La corrélation est significative au niveau 0.05 (bilatéral)

${ }^{\star *}$. La corrélation est significative au niveau 0.01 (bilatéral).

Modes de financement : funding modes; Taux d'intérêt: interest rate; charges financières: financial charges; Q2.1301: Enterprise results; q2.1304: Business turnove 